\title{
THE SOCIAL, ENVIRONMENTAL AND ECONOMIC BENEFITS OF REUSE BY CHARITY SHOPS
}

\author{
Robin Osterley ${ }^{1}$ and lan Williams ${ }^{2, *}$ \\ ${ }^{1}$ Charity Retail Association, 4th Floor, 356 Holloway Road, N7 6PA, London, United Kingdom \\ ${ }^{2}$ University of Southampton, Faculty of Engineering and Physical Sciences, S017 1BJ, Southampton, United Kingdom
}

Article Info:

Received:

18 July 2018

Revised:

31 May 2019

Accepted:

16 July 2019

Available online:

26 September 2019

Keywords:

Charity shops

Reuse

Social

Environmental

Economic

Circular economy

\section{ABSTRACT}

Charity shops are retail outlets selling mainly second-hand donated goods to raise funds for their parent charities. The charity retail sector is becoming an increasingly significant player in terms of demonstrating the benefits of reuse and how it can be practically realised. This paper provides an overview of the UK's charity retail sector and considers the social, environmental and economic benefits of charity shops. We estimate there are 11,200 charity shops in the UK that employ 23,000 staff and have a volunteer workforce of 230,000 . Approximately $95 \%$ of the clothes charity shops receive are either recycled or reused, diverting 331,000 tonnes of textiles from landfill and reducing $\mathrm{CO}_{2}$ emissions by 6.9 million tonnes in 2015/16. A key factor in understanding how charity shops contribute to social good includes understanding and quantifying how they might contribute to the development of the circular economy via the encouragement and practical realisation of reuse. We see this paper as a step in this process, flagging the social, environmental and economic benefits of charity shops and highlighting the need for additional research into the contribution of the charity retail sector to reuse and resource preservation/recovery.

\section{INTRODUCTION}

The circular economy is a relatively new concept that has been attracting a lot of recent attention. It is becoming fashionable for industrialists, businesses and politicians to talk about "closing the loop", ensuring "resource security" and "resource efficiency", and "joining the circular economy." Reuse is an important waste prevention measure as it extends product life, deferring or even eliminating the need to extract virgin raw materials to manufacture new products. In poorer countries, repair and reuse is a way of life; they contribute significantly to poverty reduction by providing an income for substantial numbers of poor and marginalized workers (Williams and Shaw, 2017). The fact that they facilitate greater material recovery is a bonus in such societies. In developed countries, reuse via buying "second hand" or "reconditioned" was traditionally the domain of the relatively poor or young people trying to look fashionable on a miserly budget. Indeed, within the European Union (EU), there has been an increasing focus on reuse, as stated under Article 11 of the EC Directive 2008/98/EC, detailing the requirement of all member states to "take measures, as appropriate, to promote the re-use of products... by encouraging the establishment and support of reuse and repair networks" (European Parliament and the Council of the European Union, 2008). However, reuse of products has come into fashion again; people are buying items that are "pre-loved" or "pre-owned" in order to make their money go further or to get more for their money (Williams and Shaw, 2017) or to make a quasi-political statement. As an example of a relevant social trend, rising numbers of people are purchasing second hand 'vintage items' of clothing partially because brands are now weaving in inspirations from past trends - essentially reviving them or introducing them to those who have yet to experience them (Cassidy and Bennett 2012) - and partially because of increasing interest by consumers in purchasing ethically sourced items (Pookulangara and Shepard, 2013).

There are various strategies for the preservation of value of products and components upon their end of use, including: direct resale, repair, upgrade, refurbishment, remanufacturing and repurposing. Reuse via direct resale in today's society takes many different forms. Large and small scale car boot sales and flea markets have been running for many years and are still very popular today (Gregson and Crewe, 1997; Gregson et al, 2013). The UK high street is home to various stores that sell second hand items, including charity shops, large multinational companies such as Cash Converters and CEX and smaller chains or independent second-hand stores. Additionally, the Internet has served as a place to sell used items ever since its 
conception, on both a local and international scale. Amazon and eBay allow second-hand items to be sold globally, whilst Gumtree, Facebook Marketplace, Freecycle and Depop allow consumers to search their local area for used products at a lower cost. Consequently, the charity retail sector is becoming an increasingly significant player in terms of demonstrating the benefits of reuse and how it can be practically realised.

Charity shops are largely a British institution. They are retail outlets selling mainly second-hand donated goods to raise funds for their parent charities. They also function as a way of raising awareness of the parent charity. The charity shop in its contemporary form stems from efforts by charities after the Second World War to raise donations for the war effort in the United Kingdom (UK). One of the first shops was established in 1947 in Oxford, when Oxfam was overwhelmed by donations from the public in response to an appeal for aid to alleviate the post war famine in Greece. Post-1985 saw a much more rapid expansion in the number of charities with shops and the number of charity shops in the UK, as charities began to realise the significant amount of money that could be made (Horne, 2000). There is still a high level of dependence of charities upon aid from the public for survival (Gaskin, 1999). Nevertheless, the Oxfam shop on Broad Street in Oxford is still in operation today (Grimsey et al, 2013).

From its origins, the UK charity retail sector has evolved and expanded considerably. Faced with increased demand driven by the economic downturn, the rising cost of living, and a shrinking public sector, charities depend more than ever on their stores as a stable source of funding (especially unrestricted funding) for the services they provide. Yet charity shops have a value beyond fundraising for parent charities. Charity shops provide valuable reuse and recycling services and inexpensive goods to an increasingly large section of the population; six in every ten of the UK's population have purchased from a charity shop in the past year, and nearly eight in every ten have donated goods (Bartlett, 2012). Charity shops are highly prevalent and established across the UK (Hyndman and McConville, 2018).

Charity shops also provide a number of important social and economic benefits to individuals - including customers, donors or volunteers - and local communities across the UK, and are increasingly vital to Britain's struggling high streets. Long before the recent recession, the effects of rising online sales and out-of-town retail growth was adversely impacting on high streets, precipitating the disappearance of 15,000 stores from town centres between 2000 and 2009 (Portas, 2011). The state of Britain's high streets would be even worse if it were not for the presence of charity shops.

In this paper, we provide an overview of the UK's charity retail sector and consider the social, environmental and economic benefits of charity shops. We would like to acknowledge that some of the paper is drawn from reports commissioned by the Charity Retail Association from Demos (www.demos.co.uk) and published Open Access (Paget and Birdwell, 2013; Harrison-Evans, 2016).

\section{THE UK'S CHARITY RETAIL SECTOR}

\subsection{Overview}

Estimates of the numbers of charity shops in the UK are a bit unreliable since surveys are carried out infrequently. Our current estimate is around 11,200 shops in the UK: $83 \%$ in England, 9\% in Scotland, 5\% in Wales and 3\% in Northern Ireland. There are over 400 shops in the Republic of Ireland. They are represented by the Irish Charity Shops Association (www.icsa.ie). We estimate that charity shops raise around $£ 270$ million for a range of causes each year.

There has been an increase in the number of paid staff in recent years, although the majority of people working in charity shops are volunteers. There are over a quarter of a million retail volunteers nationwide, and some shops are run entirely by volunteers.

Many people shop in charity shops because they want to support the activities of the parent charity. A growing number of people use charity shops because of the environmental and ethical benefits of the reuse of goods, rather than buying completely new goods, or dumping used goods. Indeed, sales of items brought in to charity shops have increased recently (CRA, 2018a). Other people shop in charity shops because they like the range of goods available. Many charity shops stock clothes, furnishings, crockery, CDs and DVDs that are no longer available in other stores. Many people visit charity shops to pick up retro and vintage clothing in particular. This reuse of textiles provides many positive benefits in terms of sustainability:

- The lifecycle of products is extended. This means that labour already input into producing existing goods is not wasted (Castellani et al. 2015);

- Less environmental damage results from collection and transport of second-hand clothing than is created by extracting virgin raw materials (Farrant et al, 2010). Approximately $95 \%$ of clothes donated to charity shops are either reused or recycled (Harrison-Evans, 2017). It was estimated that, in 2016/17, 323,000 tonnes of textiles were diverted from landfill after being donated to charity shops, which reduced $\mathrm{CO}_{2}$ emissions by around 6.8 million tonnes and saved councils $£ 27$ million in landfill tax (CRA, 2018b);

- Relatively deprived members of society benefit from redistribution of resources (Horne, 1998, 2000; Parsons, 2002; Broadbridge and Parsons, 2003; Lovatt, 2015; Harrison-Evans, 2017; Castellani et al, 2015);

- The economy is stimulated by the provision of new job opportunities and in some cases there is a specific effort to employ disadvantaged people (Castellani et al, 2015; ReDo, n.d).

Charity shops are also popular because the prices are often lower than other shops, even commercial second-hand shops. Over $90 \%$ of goods sold in charity shops are from donations. Some shops also sell 'bought-in' goods. These are new goods which are sold for profit. The average charity shop sells around $6 \%$ new goods. Many shops sell only donated goods, but others sell both boughtin and ethically produced 'fair trade' goods. A shop must sell wholly or mainly donated goods in order to retain its 
status as serving a "charitable purpose"; this is crucial in terms of charitable tax relief on business rates (see below).

Most charity shops sell ladies', men's and children's clothing, books, toys, ornaments, kitchenware, dvds, music, computer games, furnishings and bric-a-brac. Some charity shops also sell furniture and electrical appliances, and some are specialist shops, such as bookshops, bridal or music.

Charity shops benefit from tax concessions under UK tax law because all the profits from a charity shop go to fund the work of the charity, which provides public benefit. Charity shops, therefore, serve a "charitable purpose". Charity shops benefit from exemption from corporation tax on profits, a zero VAT rating on the sale of donated goods and $80 \%$ mandatory non-domestic rate relief, on property taxes. This $80 \%$ relief is funded by central Government. A further $20 \%$ rate relief is available at the discretion of local authorities. Other types of business are eligible for different sorts of relief from full business rates liability; these include small business rate relief, and relief for small shops in rural settlements.

Money that has been raised goes to the parent charity, to further their charitable work. Charity shops in the UK raise money that funds medical research, overseas aid, environmental initiatives, supporting sick and deprived children, homeless people, mentally and physically disabled people, for animal welfare and for many other causes.

At their best, charity shops can provide a highly rewarding consumer experience, giving people the satisfaction of having found a desirable item, at an attractive price, while benefiting charity and the environment in the process. Of course, the quality of charity shops can vary significantly. Some still conform to the persistent stereotype of selling damp and disordered stock, but increasingly this is becoming an outdated stereotype. Charity retail today is highly professionalised: goods are clean, shops are well stocked and displays are expertly laid out, with high quality donated brand name items at affordable prices. This shift has been driven by changing consumer expectations, an increasing trend of recruiting ex-commercial retailers to work in charity retail and increased competition - with the likes of eBay, Gumtree and cash-for-clothes shops - for donations, and low-cost high street retailers for sales. There is also a general realisation that charity retail is a significant contributor to the work of charities across Britain and - indirectly - to resource preservation.

\subsection{The Charity Retail Association}

The Charity Retail Association has its origins in the Charities Advisory Trust (CAT) in the early 1990s. The CAT was, and still is, a group dedicated to improving the effectiveness of charities, especially in their trading and income generation dimensions, and was started in 1979 by Dame Hilary Blume. Dame Hilary responded to the large increase of charity shops in the 1980s and early 1990s by offering training sessions and advice, and it soon became clear that there was an appetite for a forum dedicated to discussing the issue of retail in the charitable environment.

Thus was born the Charity Shops Group, formed at an inaugural meeting at the National Council for Voluntary Or- ganisations in 1992. CAT acted as the secretariat for the Group, which offered networking, lectures and seminars, working lunches and other ways of exchanging information. This proved so successful that it was decided to formalise the Group with a steering committee, whose first chair was Colin Sandford of the British Heart Foundation (BHF). At this point the Group was also starting to attract smaller charities as well as the established large retail chains such as Marie Curie, Shelter, Oxfam, British Red Cross, Help the Aged, BHF and others.

In the later 1990s, a national voice for the sector became increasingly sought after, especially to deal with issues such as business rates relief and value added tax (VAT). It was felt by the steering group that a more formal approach was now needed, and the members of the group co-funded a consultancy project whose conclusion was that, given the right business model, a formal association was sustainable and desirable and that there was considerable support within the sector to fund such an organisation. This led, in 1999, to a separation from CAT, and the formation of the new Association - the Association of Charity Shops (ACS). Its first conference, held in 2000 at Church House in Westminster, attracted around 200 delegates, and rapidly became a highly successful annual affair with a very successful trade exhibition attached. In the same year were launched the first website and the first special interest group, and the first corporate members joined. Subsequent years saw the introduction of a number of additional member services including a legal advice line, the members' area of the website, further special interest groups, and more emphasis on lobbying and advocacy work. In 2002, the prestigious Charity Retail Awards were started.

In 2004 ACS moved to share premises with the Association of Charitable Foundations in Bloomsbury in central London. The following years saw a gradual increase in the profile of ACS within government against a background of considerable growth within the association's membership, both charitable and corporate. The ACS changed its name to the Charity Retail Association (CRA) in 2013.

The CRA is now the leader of the charity retail sector in the UK, with over $75 \%$ of the shops in the UK under its umbrella, including the 9 of the 10 largest by income generation: British Heart Foundation; Oxfam GB; Cancer Research UK; Barnardo's; Sue Ryder; Salvation Army; British Red Cross; Scope; and Marie Curie. Examples of member services that promote reuse include:

- The "Style Me in Seconds" Toolkit; this aims to create a positive image of charity shops as fun and interesting places to shop for the younger generation;

- The "Social Value" toolkit; this aims to allow the CRA to aggregate the social value created by the charity shop movement as a whole, to build a stronger evidence base to advocate on behalf of its members and to help CRA members to make this case for themselves.

\section{METHODOLOGY}

In 2013 (and again in 2017; see below), Demos undertook a range of quantitative and qualitative research to ex- 
plore the benefits that charity shops provide, including:

- Three focus groups with experts from the charity and retail sectors, town planners and economists, and members of the public, in London and Rochdale;

- A representative survey of 2,200 members of the public - a survey of 300 charity shop managers and volunteers;

- Semi-structured interviews with charity shop managers and volunteers, independent retailers and local authority staff in six areas of the UK: Birmingham, Margate and Morpeth (England); Newport (Wales); Paisley (Scotland), Newry (Northern Ireland);

- A comprehensive review of all the available quantitative evidence from our case study areas - both local economic health indicators (including footfall, change in rental values, and vacancy rates) and trends relating to charity retail over a five year period.

During 2015 the third sector faced an unprecedented amount of criticism from a range of sources on issues such as unsolicited fundraising approaches, charity efficiency and executive pay. It was against this background that the CRA decided, in early 2016, to commission an update report from Demos, supported by the Carnegie UK Trust. This study, which provided an updated analysis of the social value created by charity shops, also employed a variety of quantitative and qualitative techniques, including:

- A survey of 650 charity shop managers and volunteers (484 managers, 192 volunteers).

- A nationally representative survey of 2,000 British citizens.

- Semi-structured interviews with senior charity retail staff, shop managers and volunteers

- An analysis of updated local economic data on the same study locations as in the 2013 report with the exception of Newry.

The work outlined in Section 4 is largely derived from Demos's studies. Details of the methods employed and the results secured are in Paget and Birdwell (2013) and Harrison-Evans (2017).

\section{BENEFITS OF CHARITY SHOPS}

\subsection{Economic benefits}

Charity retail is vital to charities' incomes and the health of the high street. While they account for only $0.39 \%$ of UK retail sales (2013), charity shops generate as much as $18.7 \%$ of UK charities' total income. They are an important lifeline for recession-hit charities, through their fundraising and by boosting their public profile; $59 \%$ of people believed that charity shops' presence on the high street encourages people to give to charity (2013). In this respect, charity retail has taken on particular importance as a source of charitable funding. At the peak of the recession the total amount given to charity declined by $13 \%$ (NVCO, 2012) and $59 \%$ of charities reported having been affected by the downturn (NVCO, 2012).

A majority of the British public shop or donate to a charity shop every year. Polling in 2017 shows that $74 \%$ of UK adults donated to charity shops in the past 12 months, and
$61 \%$ purchased at least one item from a charity shop over that same period. Although many people do so only a handful of times a year (roughly $60 \%$ of donors and shoppers donate or purchase up to five times a year), for some visiting a charity shop to drop off clothes or pick up a bargain is a regular pastime. Roughly 1 in 20 people are 'super-donors' or 'super-shoppers', doing so over 20 times a year. These donors and shoppers provide the stock and sales revenue that charity shops need. In 2015/16 charity shops generated over $£ 270$ million in profits to support the work and impact of their parent charities, equating to roughly $3 \%$ of the voluntary sector's total income. While total income generated by charity retail rose to $£ 1.3$ billion in $2015 / 16$, because of rising costs profits fell by $9 \%$ on the previous financial year.

The charity retail sector has not been immune to the recession; it has faced the challenge of meeting increased demand with a reduced supply of donated stock, as people have been more inclined to hold on to old clothes for longer or used them to generate cash. However, in a weak economic climate charities stand only to benefit from having more income streams, and retail has proved a robust and reliable one. It is also likely that the growth and continued presence of charity shops may have maintained footfall to high streets, which are suffering from the downturn as well as the longer-term effects of seismic changes in the retail landscape. Despite improvements in the wider economy since 2013, there has been little wholesale improvement in the fortunes of the high street, with some downward pressures (particularly that from online competition) intensifying. For struggling town centres, charity shops therefore continue to play a vital role in filling otherwise vacant lots, and generating footfall to at least partially offset the departure of other businesses.

Charity shops are increasingly important for members of the public due to the increased cost of living. They provide affordable goods to people on a low income. Twothirds of the public and over $90 \%$ of shop managers and volunteers thought their shops supplied affordable goods to people on a low income. The minimum cost of living in the UK rose by as much as $25 \%$ during the recent recession (Joseph Rowntree Foundation, 2016), and prices continue to rise at a much faster rate than wages. The impact is being felt at all levels of society, including the poorest and the so-called 'squeezed middle'. This is reflected in the steady broadening of charity shops' customer base. The A, B and C2 groups are the most likely to buy and to donate goods, challenging the view that charity shops are the preserve of any one socioeconomic group. A total of $38 \%$ of all social groups said they would be 'likely' or 'very likely' to buy second hand from charity shops as a way of saving money.

There is no evidence that charity shops are having an adverse economic impact on the high street. Specifically, an economic analysis of available data found that charity shops do not increase rents for other shops on the high street and do not prevent small and medium-sized businesses from opening on the high street. There is no evidence to suggest that the growth of charity shops is causing or facilitating high street decline. 
Indeed, charity shops are stabilising the high street in a difficult economic climate and will be increasingly important to the evolution of British high streets. The town of Margate provides a clear example of the role that charity shops can play in supporting high street recovery. During the recession that started in 2008, Margate's high street suffered badly, with the town recording the worst rate of shop closures in Britain in 2009, and vacancy rates jumping to nearly $40 \% 2012$. As vacancy rates began to spike, charity shops played a role in filling the gap, and the proportion of empty lots gradually decreased. Vacancy rates have now (2017) fallen to nearly half of their recessionary peak, and this improvement has accompanied a dramatic change in fortunes for the town, which has become an arts and culture hub, thanks in part to the opening of the gallery Turner Contemporary in 2011. Margate's cultural revival led it winning Pearlshare's award for being the best seaside town in Britain (2016) with judges praising the town's 'retro buzz'. Charity shops form a key part of this retro identity; some of the town's charity retailers have redesigned stores to emphasise a boutique or specialist offer. For example, the Pilgrim's Hospice retail chain has set up Frocks ' $n$ ' Socks, a shop stocking only vintage clothing and homeware, and Oasis, a local domestic violence charity, set up its first charity shop in 2014, designed to create a 'boutique feel', stocking 'retro-chic' clothing.

Thus, contrary to the view that they are having a negative impact locally, charity shops appear to be exerting a stabilising influence on ailing high streets as they have ensured that footfall remains steady, they cater to specific local needs, and they fill shops that would otherwise be empty. They are also preventing increases in crime and antisocial behaviour by occupying vacant premises. As the sector becomes more professional (e.g. using visual merchandising skills) and more specialised (e.g. setting up vintage boutiques or specialist music stores), charity shops are contributing to a more vibrant and eclectic retail mix on certain high streets. With charity shops increasingly providing access to services, they can potentially be leaders of the 'evolution' of the high street.

\subsection{Social benefits}

Charity shops provide significant benefits to individuals through opportunities for volunteering and employment. Charity shops employ an estimated 23,000 staff across the UK, and have a volunteer workforce of some 230,000 . This level of employment assists the economy as well as benefiting individuals. Approximately $6 \%$ of adults (18+) have worked or volunteered in a charity shop at some point in their lives, equating to nearly 3 million people across Great Britain. Volunteers generally report being overwhelmingly happy with their role, with $93 \%$ of those surveyed (in 2017) saying that they were satisfied, and $90 \%$ saying they would recommend their organisation as a 'great place to work'. Volunteers of different ages and backgrounds get notably different benefits from their work. For example, when asked about the most significant benefit of their volunteering role, older people most commonly cite contribution to charity or the social aspects of the role, and most younger people mention work experience, and developing skills and confidence. In addition, volunteers say that they value the chance to gain retail experience as a path to paid employment or back into employment after a period of illness or injury. Charity shops provide a place for those with poor physical or mental health to interact socially and build self-esteem and are increasingly providing opportunities for people within or leaving the criminal justice system. Job seeking volunteers most commonly cite improved confidence and self-esteem as the primary benefit of their work, and significant majorities said that they had improved their communication, team-working, problem-solving, organisational and numeracy skills. Several charity retailers, particularly the larger chains, provide volunteers with an opportunity to formally recognise their new skills through a qualification. This enables volunteers to gain a National Vocational Qualification (NVQ) in retail, customer service, visual merchandising and other related areas.

Charity shops provide a space for social interaction for volunteers and members of the public, facilitating local cohesion. Charity shops combat social isolation in their local communities among volunteers and customers. Respondents to the public survey and large numbers of volunteers and staff report that older and other vulnerable people use shops to 'drop in' for a chat. One in five members of the public said they had met or talked to someone new in a charity shop, while $30 \%$ said they provided a space for social interaction, $29 \%$ said they provided a sense of community and $28 \%$ said that charity shops encouraged different generations to meet. The employees and volunteers in charity shops are overwhelmingly from the local area, and value charity shops for social interaction. Over $90 \%$ of volunteers cited 'socialising and meeting new people' as a benefit of volunteering, while one in ten cited this as the most important benefit they received from volunteering.

Charity shops are well placed to cater to the specific needs of their local community through local partnerships and access to services. Social value is most effective where it has the flexibility to be responsive to local needs. Innovative examples of effective local partnerships include South Bucks Hospice's four-way partnership with the local council, a nearby prison and a waste management company, and a charity shop in Wales which set up a mobile sale stall in a local care home. Demos' research found that some charity shops are used as 'gateways' and signposts to charities' services and even to deliver services directly (as with housing advice at some Shelter stores). More generally, charity shops have a potential for showcasing, promoting and hosting services, which is often underexploited.

Members of the public and retailers are generally positive about charity shops on British high streets. For example, three out of four (74\%) respondents were supportive of charity shops receiving $80 \%$ business rate relief. Similarly, interviews with charity shop managers, volunteers and independent retailers highlighted the benefits of charity shops to the community and the high street. Those independent retailers who had negative attitudes towards charity shops tended to perceive them as a source of competition in an already difficult economic environment. Positive attitudes among the public were linked to transparency about how 


\subsection{Environmental benefits}

Charity shops provide significant environmental benefits through the reuse and recycling of goods, which saves landfill space and helps the UK reduce its $\mathrm{CO}_{2}$ output. Goods that are not directly sold in the UK are either sold on to textile remanufacturing plants, or sold in developing countries abroad.

The opportunity for reusing and recycling materials is the most widely recognised benefit provided by charity shops. Approximately $95 \%$ of the clothes charity shops receive are either recycled or reused. This has a significant environmental impact, diverting 331,000 tonnes of textiles from landfill in 2015/16, and in doing so reducing carbon dioxide emissions by an estimated 6.9 million tonnes per annum. Diverting clothing and other goods from landfill also has economic benefits for local councils by reducing costs of landfill tax (the tax paid by local councils for disposing of waste in landfill sites). In 2015/16 this saved UK councils an estimated $£ 27$ million.

The significant fall in the rag price in recent years (dropping from on average 45 pence to 37 pence per kilo between 2014 and 2016) has reduced the incentive for charity retailers to sell on unwanted goods to textile recyclers. This may have a positive environmental impact by encouraging charity shops to increase the reuse of donated stock. Although recycling goods is clearly preferable to sending them to landfill, it still carries with it some environmental costs, predominantly in the energy and chemicals required for the industrial recycling process. In contrast, reusing goods has none of these environmental downsides. There is emerging evidence that charity shops wish to promote greater reuse of stock in response to the fall in rag price; some retail chains have introduced discount stores as a way to sell stock that is in good condition, but was previously unwanted.

An example of a charity shop providing environmental benefits can be seen in Box 1. Recognising the environmental benefits and current fiscal incentives around reuse, some charities (including large national chains, such as Sue Ryder) have set up dedicated 'reuse' shops often located at, or near, local recycling centres. These shops have generally been developed through pioneering partnerships between charity retailers, local councils, and waste management companies, brought together by the mutual environmental and economic benefits that reuse can bring. For example, Wrexham Borough Council entered into one such partnership with waste management contractor FCC Environment and local hospice Nightingale House, launching a new store at a recycling centre in 2016. Under the partnership, staff from FCC Environment retrieve useable items from the recycling centre where the shop is located, and from two other household waste sites in the city. They clean and safety test these items before placing them in the reuse shop, run by Nightingale House. By innovating in this way charity retailers are helping to increase the proportion of goods that are reused and in doing so maximising environmental and cost saving benefits.
South Bucks Hospice (SBH) has seven shops in total. In 2012, the charity teamed up with Buckinghamshire County Council and FCC Environmental, an international waste management company, to run two of FCC's ten recycling centres. At each of these, designated 'reuse champions' identify resaleable items, which are sold at SBH's onsite reuse shops. In the first seven months of the scheme 33,512 items were sold. Over time, a very strong relationship has built up between the recycling centre and local residents. This has driven up recycling behaviour in the community, and raised awareness of the hospice.

$\mathrm{SBH}$ also has another, four-way, partnership with the council, FCC Environmental and Her Majesty's Prison (HMP) Bovingdon. Once a week, bicycles deposited at the recycling centre are sent to the prison to be repaired. SBH pays for the spare parts needed for the repairs, and sells the bikes through the reuse shops, which have sold 2,200 bicycles since July 2012 . Not only does the scheme provide an opportunity for prisoners to improve their social skills and work readiness, it also leads to a National Vocational Qualification (NVQ) in bicycle repair - a route into employment on release. All four stakeholders gained from the partnership: the county council reduced the amount of waste sent to landfill; FCC reduced its costs; local residents benefit from bargain goods; and funds are raised for the hospice.

\section{CONCLUSIONS}

Until recently, charity retail was a social good that was generally taken for granted. Charity shops encourage recycling and reuse and provide goods to people at affordable prices all the while raising income for parent charities. However, the charity retail sector - as well as the British high street and economy as a whole - is undergoing significant changes. The number of charity shops on British high streets has been rising since the early 2000s, with particular growth since the 2008 recession. Many are also becoming increasingly professionalised in their appearance and sales strategy, and are thus providing greater competition with other high street retailers and countering negative perceptions of charity shops as dusty and disorganised. A consequence of this resurgence is that the charity retail sector is becoming an increasingly significant player in terms of demonstrating the benefits of reuse (and recycling) and how it can be practically realised.

The social value of charity shops includes:

- The amount of money raised for each charity;

- Services provided by those charities with the money raised;

- The number of people employed in charity shops and resulting benefits;

- The number of people volunteering in charity shops and resulting benefits;

- Environmental impacts of reusing and recycling goods; and

- Benefits to social interaction, cohesion and offender rehabilitation.

The community benefits provided by charity retail include:

providing direct local services in local areas; promoting access to charity and other local services; providing opportunities for social interaction and cohesion; 
- forging local partnerships with local institutions;

reusing and recycling goods;

providing affordable goods; and

maintenance of footfall on local high streets that are

otherwise struggling to compete with out-of-town shopping centres and the rise of internet shopping.

There is no doubt that the total value of charity shops goes far beyond the amount of money they raise for their parent charities. Calculating a social return on investment (SROI) figure for the entire charity retail sector is incredibly difficult because of the wide range of charities that operate charity shops, as well as the range of specific activities that those charities undertake. To work towards a calculation of social value for the entire sector, each individual charity should begin to understand and quantify its own social value. A key factor in understanding how charity shops contribute to social good includes understanding and quantifying how they might contribute to the development of the circular economy via the encouragement and practical realisation of reuse. We see this paper as a step in this process, flagging the social, environmental and economic benefits of charity shops and highlighting the need for further research into the contribution of the charity retail sector to reuse and resource preservation/recovery.

\section{ACKNOWLEDGEMENTS}

The authors would particularly like to acknowledge the work of Peter Harrison-Evans, Alexandra Paget and Jonathan Birdwell from Demos.

\section{REFERENCES}

Bartlett, J. (2012). The Data Dialogue, London: Demos.

Broadbridge, A. and Parsons, L. (2003). Still serving the community? The professionalisation of the UK charity retail sector. International Journal of Retail \& Distribution Management, 31(8), 418-427.

Cassidy and Bennett (2012), The rise of vintage fashion and the vintage consumer, Fashion Practice, 4(2), 239-261.

Castellani, V., Sala, S., and Mirabella, N. (2015), Beyond The Throwaway Society: A Life-Cycle Based Assessment Of The Environmental Benefit Of Reuse. Integrated Environmental Assessment and Management, 11(3), 373-382.

Charity Retail Association (2018a), The definitive annual survey of the charity retail market: The Charity Shops Survey 2018, England: CSA, Available from: https://outlook.office.com/mail/search/id/ AAQkADU1NTFhYWEXLTFiZmQtNGZIMS1iNjBmLWUyOTIwZDgy YzY0ZgAQAFKcwrg4pkB9iKbcX4IGd5k\%3D/sxs/AQMkADU1AT FhYQEXLTFiZmQtNGZIMS1iNjBmLWUyOTIwZDgyYzY0ZgBGAA AD3KDOU4GYCEuXUJRamDjq5gcAN4OYuVK\%2Bf0i6BurUr3Q2 YQAAAgEMAAAAN4OYuVK\%2Bf0i6BurUr3Q2YQACGsA5pwAAA AESABAAv5rljFeX1kOQ\%2Fed3KPp\%2BJQ\%3D\%3D, [Accessed: 15/04/19].
Charity Retail Association (2018b). Charity Retail Association's key findings from 2017's research programme. London: Charity Retail Association.

European Parliament and the Council of the European Union (2008), Directive 2008/98/EC of The European Parliament and of the Council of 19 November 2008 on waste and repealing certain Directives.

Farrant, L., Olsen, S. T and Wangel, A (2010). Environmental benefits from reusing clothes. The International Journal of Life Cycle Assessment, 15(7), 726-736.

Gaskin, K (1999). Blurred vision: Public trust in charities. International Journal of Non-Profit and Voluntary Sector Marketing, 4(2), 163178.

Gregson, N. and Crewe, L. (1997). The Bargain, the Knowledge, and the Spectacle: Making Sense of Consumption in the Space of the CarBoot Sale. Environment and Planning D: Society and Space, 15(1), pp.87-112.

Gregson, N. and Crewe, L. (2003). Second-hand cultures. Oxford: Berg.

Grimsey, B. et al (2013). The Grimsey Review: An alternative future for the high street. Available at: http://www.vanishinghighstreet.com/ wp-content/uploads/2016/03/GrimseyReview04.092.pdf (accessed 4 Nov 2013).

Harrison-Evans, P. (2017). Shopping for good: the social benefits of charity retail. Available at: https://www.demos.co.uk/project/ shopping-for-good/ (accessed 26 Feb 2018).

Horne, S. (1998). Charity shops in the UK. International Journal of Retail \& Distribution Management, 26(4), 155-161.

Horne, S. (2000). The charity shop: purpose and change. International Journal of Nonprofit and Voluntary Sector Marketing, 5(2), 113124.

Hyndman, N and McConville (2018). Trust and accountability in UK charities: Exploring the virtuous circle. The British Accounting Review, 50(2), 227-237.

Joseph Rowntree Foundation (2016). Households below a minimum income standard: 2008/09-2013/14. Available at: https://www. jrf.org.uk/report/households-below-minimum-income-standard-200809-201314 (accessed Oct 2013).

Lovatt, M. (2015). Charity Shops and the Imagined Futures of Objects: How Second-Hand Markets Influence Disposal Decisions when Emptying a Parent's House. Culture Unbound: Journal of Current Cultural Research, 7(1), 13-29.

National Council for Voluntary Organisations (NVCO) Civil Society Almanac (2012). What impact did the recession have upon the voluntary sector? Available at: https://data.ncvovol.org.uk/a/almanac12/almanac/voluntary-sector/finance-thebig-picture/what-impact-did-the-recession-have-upon-thevoluntary-sector/ (accessed Oct 2013).

Paget, A. and Birdwell, J. (2013). Measuring the social value of charity shops. Available at: https://www.demos.co.uk/files/DEMOS_givingsomethingbackREPORT.pdf?1385343669 (accessed 20 Feb 2018).

Parsons, E. (2002). Charity retail: past, present and future. International Journal of Retail \& Distribution Management, 30(12), 586-594.

Pookulangara, S. and Shepard, A. (2013), Slow fashion movement: Understanding consumer perceptions- An exploratory study, Journal of Retailing and Consumer Services, 20(2), 200-206.

Portas, M. (2011). The Portas Review: An independent review into the future of our high streets. Available at: https://www.gov. uk/government/uploads/system/uploads/attachment_data/ file/6292/2081646.pdf (accessed 4 Nov 2013).

ReDo (n.d). ReDO's Mission, Available from: http://loadingdock.org/ redo/index.htm, [Accessed: 28/03/19].

Williams, I.D. and Shaw, P.J. (2017). Editorial: Reuse: Fashion or future? Waste Management, 60, 1-2. 